\title{
Effects of climate change on growth of 0-group sole and plaice
}

\author{
Lorna R. Teal ${ }^{1}$, Joep J. de Leeuw ${ }^{1}$, Henk W. van der Veer ${ }^{2}$, Adriaan D. Rijnsdorp ${ }^{1, *}$ \\ ${ }^{1}$ Wageningen IMARES (Institute for Marine Resources and Ecosystem Studies), PO Box 68, 1970 AB Ijmuiden, \\ The Netherlands \\ ${ }^{2}$ Royal Netherlands Institute for Sea Research (NIOZ), POBox 59, 1790 AB Den Burg, The Netherlands
}

\begin{abstract}
The effect of rising seawater temperature on growth of 0-group sole Solea solea and plaice Pleuronectes platessa in the southeastern North Sea was investigated for the period 1970 to 2004 using annual autumn pre-recruit survey data and frequent surveys on a nursery ground. Autumn length showed an increasing trend in sole but not in plaice. Increasing winter temperatures significantly increased the growing period of sole, a warm-water species that spawns in spring, but not of plaice, a temperate species that spawns in winter. Growth rate increased with higher summer temperatures in sole and to a lesser degree in plaice. Compared to experimental growth rates at ambient temperatures and unlimited food, observed growth rates were close to experimental values until mid-June but were much lower in July to September, suggesting food limitation in summer. The higher temperatures observed since 1989 positively affected the quality of the shallow coastal waters as a nursery area for sole but not for plaice. A further increase may negatively affect the nursery quality if the production rate of benthic food cannot meet the increase in energy requirements of 0-group flatfish.
\end{abstract}

KEY WORDS: Climate change $\cdot$ Temperature $\cdot$ Growth $\cdot$ Food limitation $\cdot$ Juvenile $\cdot$ Sole $\cdot$ Solea solea Plaice $\cdot$ Pleuronectes platessa $\cdot$ Spawning time $\cdot$ North Sea

\section{INTRODUCTION}

The oceanographic conditions of the North Sea are determined by the inflow of saline Atlantic water through the northern entrances and to a lesser extent through the English Channel. The temperature of the North Sea is controlled by local solar heating and heat exchange with the atmosphere (ICES 2005). Since 1989, large positive temperature anomalies have occurred in the North Sea (Becker \& Pauly 1996) and a distinct increasing trend in sea surface temperatures of the North Sea has been observed as a result of a warming climate (ICES 2005).

Many biological fluctuations in the oceans are related to changes in sea temperature, allowing effects of expected global warming to be predicted. It is evident from long-term biological data series that the North Sea ecosystem is undergoing changes at all trophic levels from phytoplankton to fish (Reid et al.
1998, Genner et al. 2004, Weijerman et al. 2005). The observed changes can be due to a direct response of the biological system to changes in the physical environment or to shifts between multiple stable states driven by the internal dynamics of the ecosystem (Scheffer \& Carpenter 2003, de Roos \& Persson 2002). Although many correlations between physical variables (e.g. temperature, salinity, wind and currents) and biological data sets have been presented (Beare et al. 2002, Beaugrand 2004), the mechanisms linking the two are still poorly understood and interpretations remain speculative.

Shallow coastal areas are particularly sensitive to rising temperatures. Productivity of coastal waters may be affected by temperature (Beukema 1992, Kröncke et al. 1998, Phillippart et al. 2003), although other factors such as eutrophication and fisheries (Rijnsdorp \& van Leeuwen 1996) may also play a role. In the Wadden Sea an increase in primary and secondary 
production coincided with an increased input of nitrates and phosphates in the 1960s and 1970s (Beukema \& Cadée 1988, Colijn et al. 2002). It is expected that productivity in this area has decreased since the mid-1980s in response to the reduction in nutrient input (Boddeke \& Hagel 1995, Lenhart 2001), but this is still under debate (Cadée \& Hegeman 2002, Philippart et al. 2007).

The coastal waters of the southeastern North Sea are important nursery grounds for juvenile flatfish like sole Solea solea and plaice Pleuronectes platessa (Zijlstra 1972, van Beek et al. 1989). Detailed studies suggest that growth of 0-group flatfish is determined by ambient temperature conditions and not by food conditions (van der Veer \& Witte 1993), as has been reported for sole (Pihl 1989, Rogers 1994, van der Veer et al. 2001, Amara 2003, 2004), plaice (Zijlstra et al. 1982, van der Veer \& Witte 1993, Amara 2003) and flounder (Pihl 1989, van der Veer et al. 1991). Only a few studies provided evidence for reduced growth in plaice (Nash et al. 1994), either through intra-specific competition (Rijnsdorp \& van Leeuwen 1992, Modin \& Pihl 1994) or through changes in the abundance or quality of food (Berghahn et al. 1995). On a large spatial scale, however, indirect support for the role of food quality and/or quantity is provided by the observed increase in growth of juvenile plaice and sole in the 1960s and 1970s (Rijnsdorp \& van Leeuwen 1992, 1996, Millner \& Whiting 1996), which could be related to the eutrophication of the coastal waters and the observed increase in benthic biomass (Reise 1982, Beukema \& Cadée 1988, Beukema et al. 2002). Therefore, changes in productivity may affect the productivity of flatfish stocks in the North Sea through growth and survival of juveniles (van der Veer et al. 1994).

The aim of the present study is to determine the effect of rising temperatures on the nursery function of North Sea coastal waters for 2 flatfish species that differ in their temperature preferences: sole, a warmwater species distributed throughout the Mediterranean and reaching the northern limit in the North Sea, and plaice, a temperate species distributed from the Bay of Biskay up to the Barents Sea and Iceland (Whitehead et al. 1986). We analysed the inter-annual variation in the mean lengths that 0 -groups reach after their first growing season to disentangle the effect of temperature on (1) the rate of growth and (2) the duration of the growth period. A comparison of the observed growth rates with experimental growth rates at the ambient temperature and unlimited food (Fonds \& Saksena 1977, Fonds et al. 1992) was used to determine if and when reduced growth may occur (cf. Zijlstra et al. 1982, van der Veer \& Witte 1993). The implications of a further increase in temperature in combination with a possible decrease in the benthic pro- ductivity on the quality of coastal nursery grounds for these 2 important flatfish species will be discussed.

\section{MATERIALS AND METHODS}

Data. Two data sets were used: (1) the Demersal Fish Survey (DFS) and (2) Balgzand Survey (BZS). The DFS aims at obtaining an estimate of the year class strength of 0-group plaice and sole and is used in stock assessment and management advice. The BZS aims at studying settlement, growth and mortality of 0-group flatfish.

The DFS has been carried out annually in September through October since 1969 along the Dutch, German and Danish coasts between $51^{\circ}$ and $55^{\circ} 30^{\prime} \mathrm{N}$, including the Scheldt Estuary, the Wadden Sea and the EmsDollard (Fig. 1), thus covering the important nursery grounds of the southeastern North Sea. The RV 'Isis' used a $6 \mathrm{~m}$ beam trawl to survey the coastal areas, whereas RV 'Stern' (Wadden Sea) and RV 'Schollevaar' (Scheldt Estuary) used $3 \mathrm{~m}$ beam trawls. All trawls were rigged with a shrimp net with bobbin rope, 1 tickler chain and a mesh size in the cod end of $10 \times$ $10 \mathrm{~mm}$. Trawling speed was 2 to 3 knots and every year 200 to 300 hauls of 15 min were carried out at a set of fixed stations. The depth of the hauls ranged from 1 to $45 \mathrm{~m}$, but the main survey area was shallower than $25 \mathrm{~m}$, where the 0-group fish are also more abundant. The total length of fish measured was rounded down to the next $\mathrm{cm}$. The length distribution of each haul was

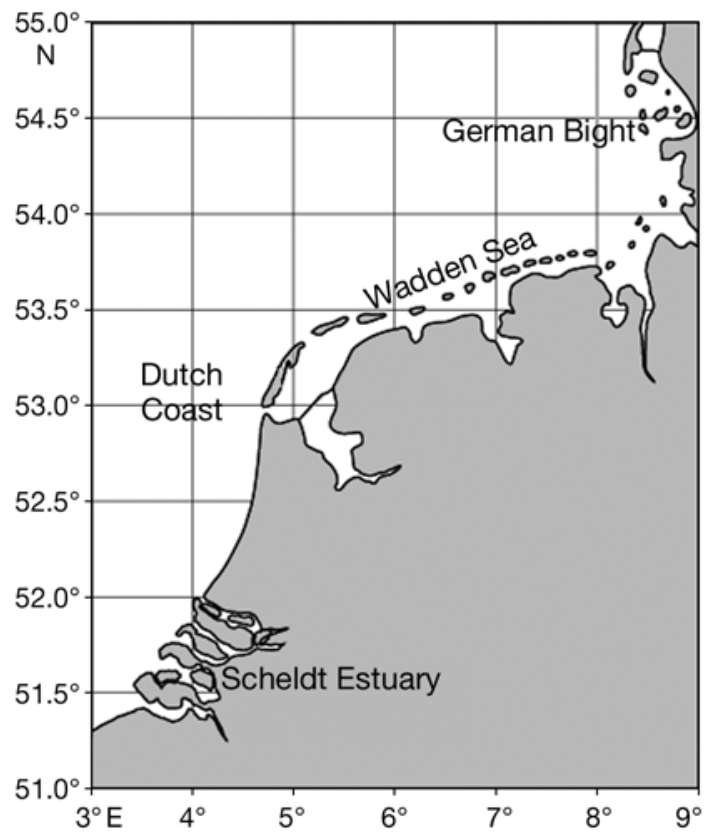

Fig. 1. Study area sampled annually in the Demersal Fish Survey and the Balgzand survey 
converted into an age distribution using otolith samples collected by sampling area each year (van Beek et al. 1989), and mean lengths were calculated for each age group.

The BZS sampled the ca. $50 \mathrm{~km}^{2}$ tidal flat area Balgzand $\left(52^{\circ} 54^{\prime}\right.$ to $52^{\circ} 59^{\prime} \mathrm{N}, 4^{\circ} 48^{\prime}$ to $4^{\circ} 55^{\prime} \mathrm{E}$ ) bordering the westernmost inlet of the Wadden Sea at frequent intervals of 2 to 4 wk between March and August in the 17 years between 1973 and 2002. A grid of 36 stations distributed over the area was sampled at a period of $3 \mathrm{~h}$ around high water. Hauls of ca. $100 \mathrm{~m}$ in length were made during daytime with a $1.9 \mathrm{~m}$ beam trawl (1 tickler chain, net mesh size of $5 \times 5 \mathrm{~mm}$ ) towed by a rubber dinghy with a $25 \mathrm{HP}$ outboard motor at a speed of ca. $35 \mathrm{~m} \mathrm{~min}^{-1}$. Length of the hauls was assessed with a meter wheel fitted to the trawl. Catches were deep-frozen and then sorted within a few days. 0 -group plaice and sole were measured to the nearest $\mathrm{mm}$ total length. Numbers of plaice and sole were corrected for size-selective mesh and catch efficiency and converted into numbers per $1000 \mathrm{~m}^{2}$. Further details of the method are given in van der Veer et al. (2000b).

Growth analysis. DFS data: Linear regression models were performed to determine trends of autumn mean lengths over the $34 \mathrm{yr}$ study period and to find relationships with temperature and length of growing period for the 2 species. Since some of the co-variables that may affect growth rate were available on the level of the individual tow, and others at the level of the year, a stepwise approach was adopted. First, the effect of covariables measured at the level of the individual tow (sampling location, depth, date and local density) was estimated using a generalised linear model (GLM; Model 1). Model 2, comprising all significant co-variables of Model 1 as well as the class variable year, was used to estimate the annual mean length standardized for the mean sampling location $\left(53^{\circ} \mathrm{N}, 5^{\circ} \mathrm{E}\right)$, depth $(10 \mathrm{~m})$, date (Day $272=29$ September) and local density (sole: 1.0 fish $1000 \mathrm{~m}^{-2}$; plaice: 12 fish $1000 \mathrm{~m}^{-2}$ ). Model 3 analysed the effect of the temperature during the survey period on growth rate by replacing the class variable year in Model 2 by the interaction between the sampling date and temperature. Model 4 analysed the standardized mean lengths from Model 2 in relation to the co-variables for which only an annual value was available (temperature during the growing period, start of the growing season, year class strength and eutrophication). The models used are summarised in Table 1.

BZS data: Growth rates during the growing season were estimated from the increase in the mean length for all hauls between successive sampling periods on the Balgzand.

Experimental growth with unlimited food. Given the mean monthly temperatures measured in Marsdiep, the entrance of the western Wadden Sea
Table 1. Explanatory variables included in the generalised linear models (GLMs) used to analyse the variation in the mean length of the 0-group. $L_{\mathrm{i}}$ is the mean length in individual hauls. $L_{\mathrm{m}}$ is the mean length by year as estimated from Model 2 for average depth, geographic location and relative density per haul. Explanatory variables are Depth $(D)$, Latitude (Lat), Longitude (Lon), Sampling date (Day), Relative catch rate in haul $(C)$, Year (YR), Temperature during survey period $\left(T_{\mathrm{s}}\right)$, Temperature during the growth period $\left(T_{\mathrm{g}}\right)$, Start of the growing period $(S)$, year class strength (YCL) and eutrophication (DIP). YR and YCLS are included as class variables

$$
\begin{array}{ll}
\text { Model } \\
\hline 1 & L_{\mathrm{i}}=D+\text { Lat }+ \text { Lon }+ \text { Day }+C \\
2 & L_{\mathrm{i}}=D+\text { Lat }+ \text { Lon }+ \text { Day }+C+\text { YR } \\
3 & L_{\mathrm{i}}=D+\text { Lat }+ \text { Lon }+ \text { Day }+C+\left(\text { Day } \times T_{\mathrm{s}}\right)+\left(\text { Day } \times T_{\mathrm{s}}{ }^{2}\right) \\
4 & L_{\mathrm{m}}=S+T_{\mathrm{g}}+\mathrm{YCL}+\mathrm{DIP}
\end{array}
$$

(www.nioz.nl), a spatially central position in the present study area, the daily growth rates were estimated based on experimentally determined relationships between growth rate and temperature at unlimited food conditions from Fonds \& Saksena (1977) and Fonds et al. (1992). Growth $\left(\mathrm{mm} \mathrm{d}^{-1}\right)$ could be described as a function of temperature $\left(T,{ }^{\circ} \mathrm{C}\right)$ :

Sole $=-3.73 \times 10^{-4} T^{3}+1.692 \times 10^{-2} T^{2}-1.384 \times 10^{-1} T+0.323 ;$

Plaice $=-1.78 \times 10^{-4} T^{3}+5.10 \times 10^{-3} T^{2}+1.04 \times 10^{-2} T-1.10 \times 10^{-2}$

Experimental growth curves were calculated for 1975 to 1988 and from 1990 to 2002, 2 periods with contrasting temperature conditions (see below).

Start of the growing season. A direct estimate of the start of the growing season was available from the peak occurrence of 0-group in the BZS data. This estimate was available in plaice for $17 \mathrm{yr}$ and in sole for $13 \mathrm{yr}$. In order to obtain estimates for the $35 \mathrm{yr}$ study period between 1970 and 2004, the start of the growing period was estimated from the regression of the date of peak occurrence against the date of the end of spawning, determined from market samples of commercial fisheries landings.

BZS data: The date of maximum density of 0-group on the Balgzand was estimated by fitting the regression through the $\log _{\mathrm{e}}$ transformed densities $(\ln y)$ against the sampling date $(x)$ :

$$
\ln y=a+b x+c x^{2}
$$

and determining the maximum at $x=-b(2 c)^{-1}$. Data included in the analysis were restricted to 5 sampling periods around the peak in abundance.

Market sampling data: The timing of spawning was estimated from the gradual progression of adult fish from the ripening to spawning and spent stage, using market sampling data collected around the spawning period (plaice: December to April; sole: February to June; de Veen 1970, Rijnsdorp 1989). The date when 
$50 \%$ of the female population had finished spawning was estimated using logistic regression of the proportion of spent females per sample against the sampling day (Rijnsdorp et al. 2005). The use of this proxy is supported by the positive correlation with the date of peak spawning observed in egg surveys (sole: van der Land 1991; plaice: Harding et al. 1978, Heessen \& Rijnsdorp 1989, van der Land et al. 1990, ICES 2006a): sole: $\mathrm{r}=0.83 ; \mathrm{p}>0.05$; $\mathrm{n}=4$; plaice: $\mathrm{r}=0.68, \mathrm{p}<0.05 ; \mathrm{n}=9$.

Temperature. Temperature data were available for 3 coastal locations in the present study area: $\sim 4 \mathrm{n}$ mile off the Blankenberge $\left(51^{\circ} 20^{\prime} \mathrm{N}\right)$, the Marsdiep tidal channel entering the Wadden Sea $\left(53^{\circ} \mathrm{N}, \sim 5^{\circ} \mathrm{E}\right.$ ) (van Aken 2003 ) and Helgoland (54 $4^{\circ}$ to $54^{\circ} 30^{\prime} \mathrm{N}$, $7^{\circ} 30^{\prime}$ to $8^{\circ} \mathrm{E}$ ) (Fig. 2a). The Marsdiep time series of monthly mean sea surface temperature (SST) data was used as an indication of the changes and inter-annual variations in temperature in the coastal waters of the southeastern North Sea, as it was significantly correlated with the monthly mean SST at Helgoland $(\mathrm{r}=0.91, \mathrm{n}=34, \mathrm{p}<0.01)$ and off the Belgian coast $(r=0.73$, $\mathrm{n}=14, \mathrm{p}<0.01)$. Despite the interannual variation, temperatures during the 1990s were noticeably higher than during the 1970s and 1980s, and an increasing trend since 1989 was evident.

Nutrients. The load of dissolved inorganic phosphate (DIP, mol s${ }^{-1}$ ) in the river Rhine at Lobith (van Raaphorst \& de Jonge 2004) was used as an index of the nutrient input into coastal waters, which via an effect on primary production may affect benthic food conditions for flatfish on the nursery grounds (Boddeke \& Hagel 1995, Philippart et al. 2007). Dissolved inorganic nitrate (DIN) follows the same trend as DIP $(\mathrm{r}=0.47, \mathrm{n}=35, \mathrm{p}<0.01)$ with increasing loads from 1970 to a maximum in the 1980s followed by a decrease, although the decline in DIN in recent years is less pronounced than that in DIP (Fig. 2b).

Year class strength. Fig. 2c shows the variations in year class strength as estimated by virtual population analysis (VPA) of commercial catches (ICES 2006b). Mean number of 1-group fish was estimated at 1.19 million plaice (coefficient of variation, $\mathrm{CV}=66 \%$ ) and 0.12 million sole $(\mathrm{CV}=74 \%)$. VPA estimates were sig-
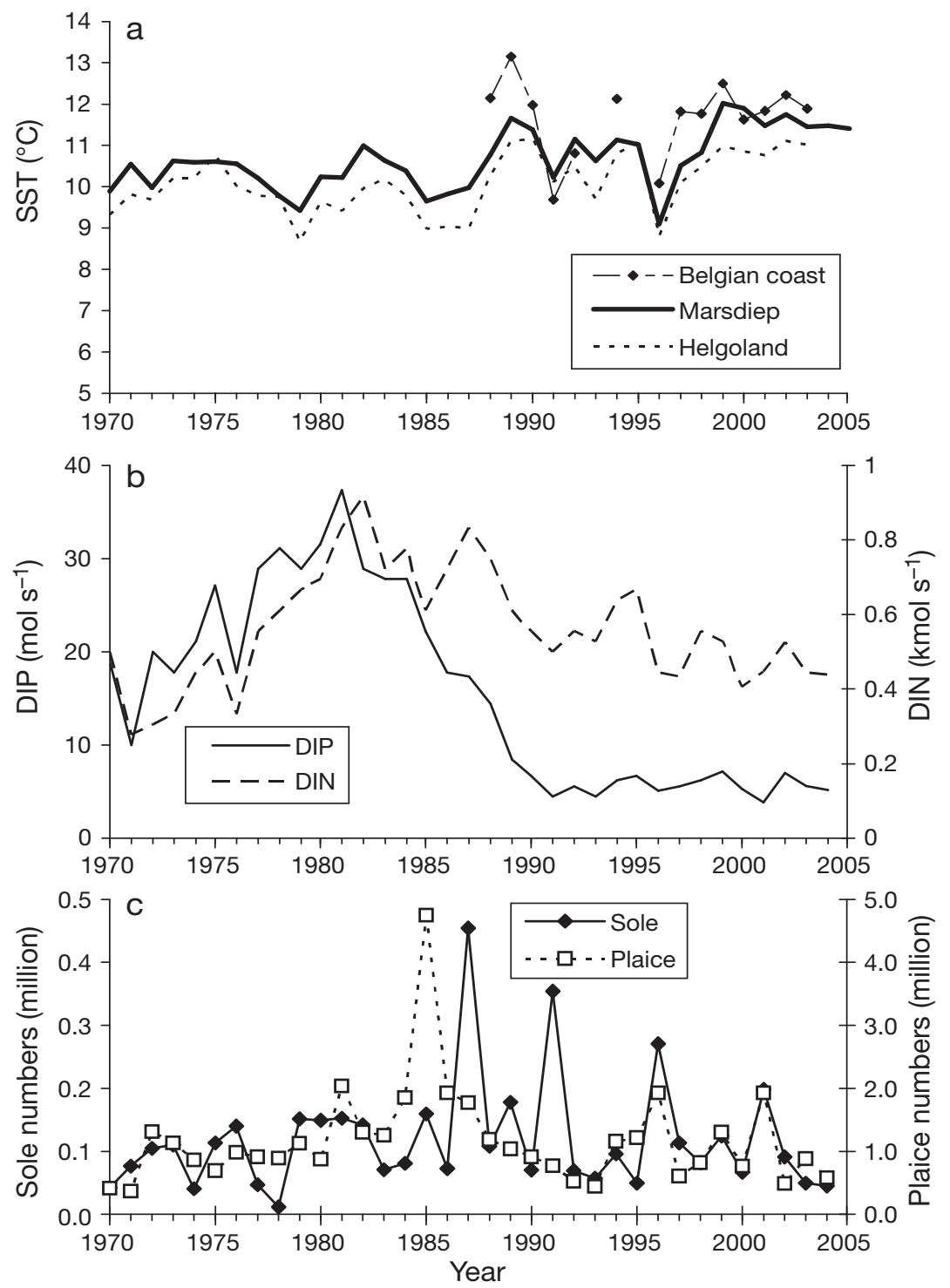

Fig. 2 (a) Annual mean sea surface temperature $\left(\mathrm{SST},{ }^{\circ} \mathrm{C}\right)$ at Den Helder. Adapted from van Aken (2003 and expanded on). (b) Load of dissolved inorganic nitrate (DIN, $\mathrm{kmol} \mathrm{s}^{-1}$ ) and phosphate (DIP, $\mathrm{mol} \mathrm{s}^{-1}$ ) in the river Rhine at the German/Dutch border, adapted from van Raaphorst \& de Jonge (2004 and expanded on). (c) Year class strength (in millions) of 1-group North Sea sole Solea solea and plaice Pleuronectes platessa estimated by virtual population analysis of commercial catches (ICES 2006b)

nificantly correlated with the abundance of 0 -group in the DFS survey (plaice: $\mathrm{r}=0.48, \mathrm{p}<0.01$; sole: $\mathrm{r}=0.36$, $\mathrm{p}<0.05)$.

\section{RESULTS}

\section{Trends in mean lengths}

The mean length and 95\% confidence limits of 0 -group sole and plaice was estimated for the average sampling date, depth, geographic position and catch 
rate using GLM Model 2 (see 'Growth rate'). Between 1970 and 2004 mean lengths of 0-group sole increased significantly by over $2 \mathrm{~cm}$ (Fig. 3 ; $\mathrm{r}=0.73$, $\mathrm{n}=35, \mathrm{p}<0.001)$. The inter-annual variation was large, and rather than being a steady linear increase, the main increase appeared to have occurred between 1988 and 1990. Length of 0-group plaice varied without a clear trend $(\mathrm{r}=0.1, \mathrm{n}=35, \mathrm{~ns})$.

\section{Start of the growing season}

In both species the end of the spawning period has shifted to an earlier date in recent years (Fig. 4), coinciding with increased winter SST (Tables 2 \& 3). On average sole finished spawning in midJune (mean day = Day 164, SD = 11) Between 1988 and 1990 a shift to an advanced spawning period occurred. Since the beginning of the 1990s, spawning ended ca. 20 d earlier than in the previous $20 \mathrm{yr}$, but spawning was late again during the cold year of 1996. The advance in the end of spawning (5.32 d per $1{ }^{\circ} \mathrm{C}, \mathrm{SE}=0.83$ ) was best explained by March temperatures ( $\mathrm{r}=$ 0.73, $\mathrm{n}=35, \mathrm{p}<0.01)$. Plaice ended spawning in late February on average $($ mean day $=$ Day 54, SD = 7). Although less distinct than for sole, a similar shift to an advanced spawning was observed ca. 1989, and in 2001 spawning ended the earliest it had in the past $30 \mathrm{yr}$ (Fig. 4). The advance in the end of spawning $\left(1.88 \mathrm{~d}\right.$ per $\left.1{ }^{\circ} \mathrm{C}, \mathrm{SE}=0.49\right)$ was best explained by February temperatures $(\mathrm{r}=0.55, \mathrm{n}=35, \mathrm{p}<0.05)$.

The date of the peak occurrence of settled plaice and sole at Balgzand was significantly correlated with the estimated end of spawning (Fig. 5). The average start of the growing season was on Day 183 (SD = 20, $\min$. = 139, $\max .=219)$ for sole and Day $105(\mathrm{SD}=$ 18 , $\min .=67, \max .=135$ ) for plaice . The effect of winter temperature on the length of the growing period revealed that an increase in winter temperature of $1 \mathrm{SD}$ above the mean advanced the end of spawning by $16.3 \mathrm{~d}$ in sole and $7.5 \mathrm{~d}$ in plaice, and the start of the growing period by $28.1 \mathrm{~d}$ in sole and $8.9 \mathrm{~d}$ in plaice, as com-

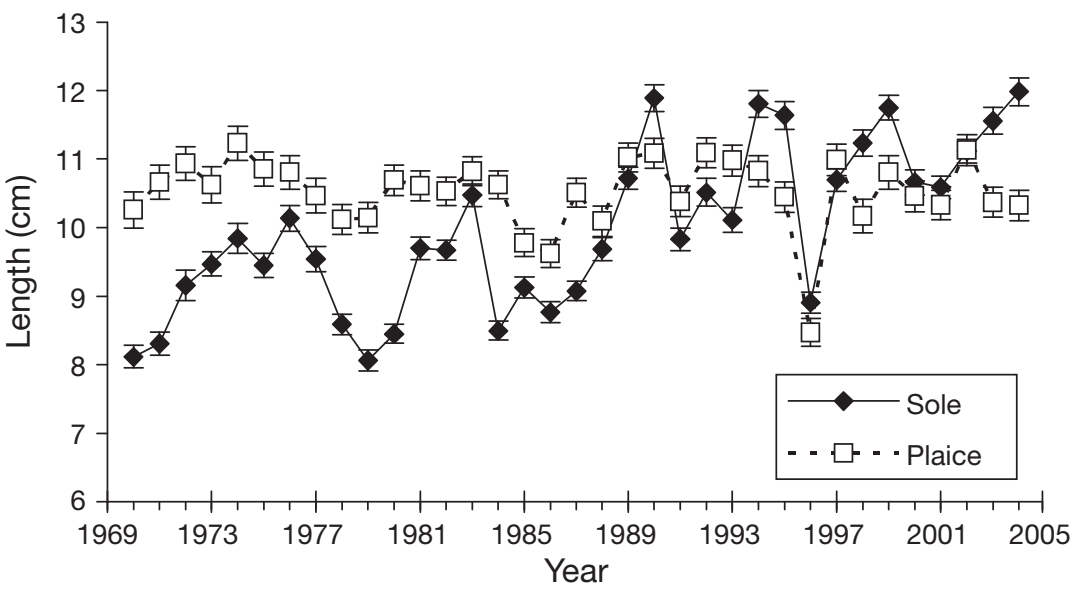

Fig. 3. Solea solea and Pleuronectes platessa. Predicted mean lengths (cm) of 0 -group sole and plaice at an average sampling date (29 September), depth $(10 \mathrm{~m})$, geographic position $\left(53^{\circ} \mathrm{N}, 5^{\circ} \mathrm{E}\right)$ and relative density (Model 2). Error bars show $95 \%$ confidence limits
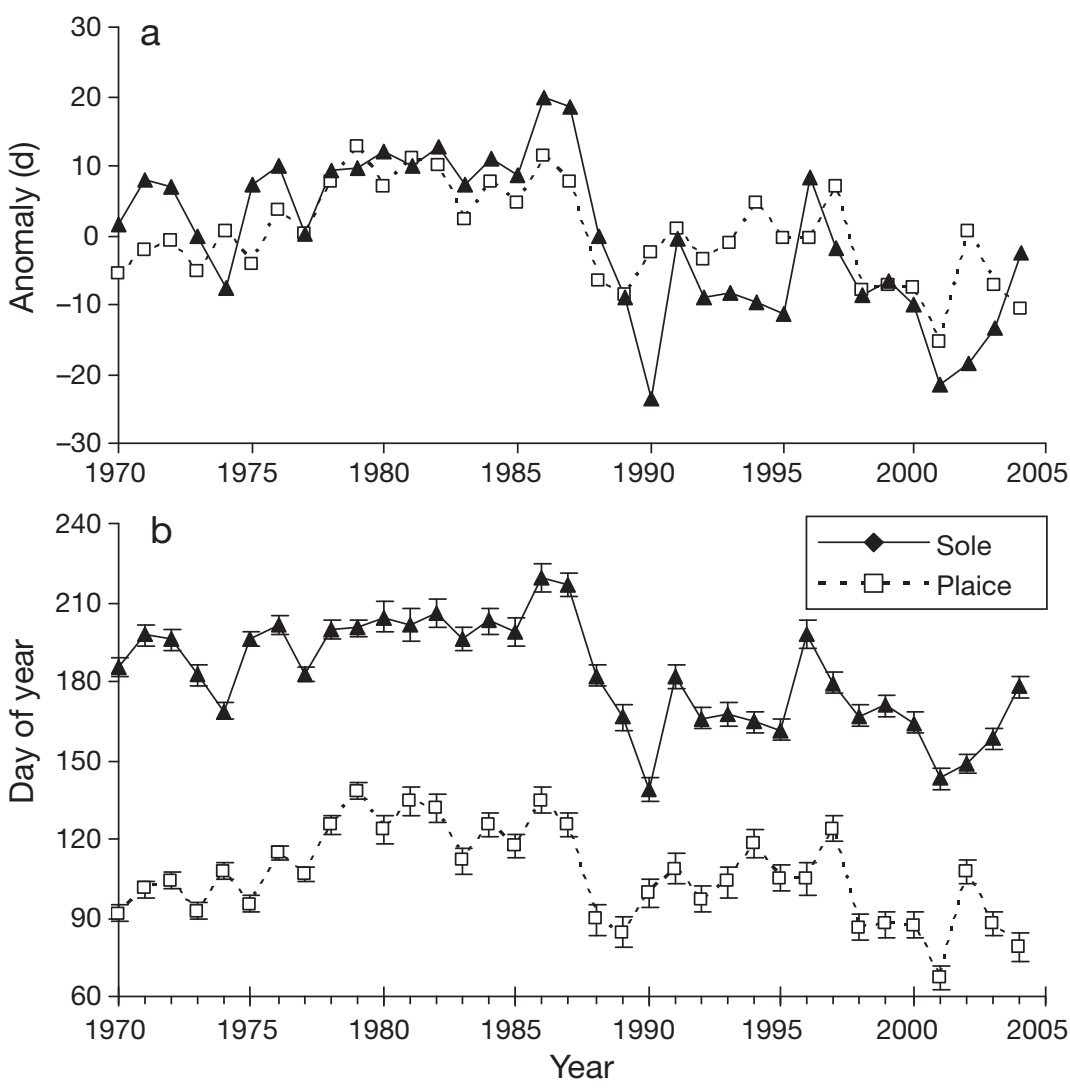

Fig. 4. Solea solea and Pleuronectes platessa. (a) Inter-annual variations in the end of spawning of sole and plaice expressed as the anomaly (d) from the average date (sole = Day 164, plaice $=$ Day 54). (b) Inter-annual variations in the start of the growing season of sole and plaice

pared to a year with a temperature of $1 \mathrm{SD}$ below the mean. The length of the growing period, defined as the period between the start of the growing period and the mean DFS sampling date, ranged between 65 and $94($ mean = 79) d in sole and between 164 and 
Table 2. Solea solea and Pleuronectes platessa. Model 1 parameter estimates and percentage of deviance in the mean length of 0 -group sole and plaice in individual tows explained by co-variables measured at the level of the individual tows. ns: not significant

\begin{tabular}{|lccccc|}
\hline & Estimate & SE & $\%$ explained & df & $p$ \\
\hline Sole & & & & & \\
Depth & 0.04 & 0.003 & $1.80 \%$ & 1 & $<0.001$ \\
Latitude & 0.429 & 0.036 & $1.10 \%$ & 1 & $<0.001$ \\
Longitude & -0.458 & 0.025 & $2.50 \%$ & 1 & $<0.001$ \\
Sampling day & 0.023 & 0.001 & $1.90 \%$ & 1 & $<0.001$ \\
Relative catch rate & 0.001 & 0.003 & $0.00 \%$ & 1 & ns \\
Plaice & & & & & \\
Depth & 0.102 & 0.0035 & $7.20 \%$ & 1 & $<0.001$ \\
Latitude & 0.986 & 0.0463 & $3.80 \%$ & 1 & $<0.001$ \\
Longitude & -0.7798 & 0.0325 & $4.90 \%$ & 1 & $<0.001$ \\
Sampling day & 0.0353 & 0.0018 & $3.10 \%$ & 1 & $<0.001$ \\
Relative catch rate & -0.053 & 0.0069 & $0.50 \%$ & 1 & $<0.001$ \\
\hline
\end{tabular}

Table 3. Solea solea and Pleuronectes platessa. Percentage of deviance by the generalised linear (GLM) models of mean length of 0 -group sole and plaice in individual tows explained by co-variables measured at the level of the individual tows. YR: year; Day: sampling day; $T_{\mathrm{s}}$ : temperature during the survey period; AIC: Akaike's information criterion

\begin{tabular}{|llccc|}
\hline Model & & \% explained & df & AIC \\
\hline Sole & & & & \\
1 & Model 1 & 7.4 & 4 & 24600.9 \\
2 & Model 1 + YR & 52.6 & 38 & 20305.9 \\
3a & Model 1 + Day $\times T_{\mathrm{s}}$ & 12.2 & 5 & 24256.9 \\
3b & Model 1 + Day $\times T_{\mathrm{s}}+\left(\right.$ Day $\left.\times T_{\mathrm{s}}{ }^{2}\right)$ & 12.8 & 6 & 24214.6 \\
Plaice & & & & \\
1 & Model 1 & 19.8 & 5 & 34980.7 \\
2 & Model 1 + YR & 27.0 & 39 & 34244.0 \\
3a & Model 1 + Day $\times T_{\mathrm{s}}$ & 21.0 & 6 & 34858.0 \\
3b & Model 1 + (Day $\left.\times T_{\mathrm{s}}\right)+\left(\right.$ Day $\left.\times T_{\mathrm{s}}{ }^{2}\right)$ & 21.3 & 7 & 34823.0 \\
\hline
\end{tabular}

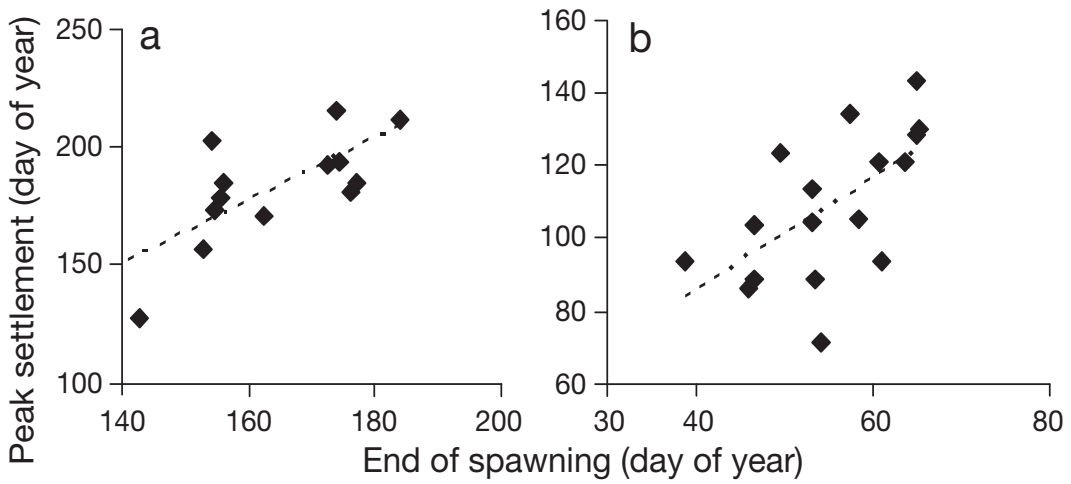

Fig. 5. Solea solea and Pleuronectes platessa. Relationship between the day of peak settlement of 0-group at Balgzand and the date of the end of spawning for (a) sole and (b) plaice

$173($ mean $=169) \mathrm{d}$ in plaice. One SD difference in winter temperature thus translated into an $18 \%$ change in duration of growing period in sole but only a $3 \%$ change in plaice.

\section{Growth rate}

DFS data

Sampling depth had a significant positive effect on 0-group body length (Table 4), although the effect on plaice was 3 times larger than for sole. Position also showed a strong signal with lengths increasing towards the North and decreasing towards the East. It should be noted that in the present study area, because of the shape of the coast in the Wadden Sea, a slight northerly shift may be combined with a large shift eastward; thus, the positive effect of the northerly position may be outweighed by the negative effect of the easterly position. The effect of sampling date provided an estimate of growth rates during the sampling period (September). Growth rates in September were estimated at $0.023 \pm$ $0.001 \mathrm{~cm} \mathrm{~d}^{-1}$ for sole and at $0.035 \pm$ $0.002 \mathrm{~cm} \mathrm{~d}^{-1}$ for plaice (Tables $2 \& 3$ ). Relative catch rate in the haul did not show an effect on sole but had a significant negative effect on plaice lengths. These factors in Model 1 explained $7.4 \%$ of the variability in mean lengths of 0 -group sole and $19.8 \%$ of variability in plaice.

The 0-group length showed large inter-annual variations. The class variable year explained $45.2 \%$ and $8.2 \%$ of the deviance in sole and plaice, respectively (Model 2, Tables 2 \& 3). To test the effect of temperature on growth rate, the class variable year was replaced by the interaction between Day $\times T$ (Model 3a). The interaction term increased the explained variance to 12.8 and $21.3 \%$ in sole and plaice, respectively (Tables 2 \& 3). Temperature positively affected the growth rate. The temperature effect was larger for sole than for plaice. Addition of the interaction of the $T^{2} \times$ Day (Model 3b) was also significant, revealing that the temperature effect on growth rate in plaice was dome-shaped with a maximum ca. $20^{\circ} \mathrm{C}$. In sole, the relationship was concave up and the maximum was outside the range of temperatures observed over the years in September. 
Table 4. Solea solea and Pleuronectes platessa. Model 4 parameter estimate, SE and the percentage of the explained (expl) deviance in the annual mean length of 0-group $\left(L_{\mathrm{m}}\right)$ that can be ascribed to the start of the growing period $(S)$, the mean temperature during the growing period ( $T$ sole: 3rd quarter [Q3]; $T$ plaice: Q2+3), the $\log _{\mathrm{e}}$ year class strength (YCL) and eutrophication (DIP). The effect of the co-variables was tested against the full model. The $L_{\mathrm{m}}$ was estimated as the year effect in Model 2 and scaled to the average location, depth, and catch rate per tow. ns: not significant

\begin{tabular}{|lrrrrc|}
\hline & Estimate & SE & $\%$ expl & df & $\mathrm{p}$ \\
\hline Sole & & & & & \\
$S$ & -0.049 & 0.016 & 9.0 & 1 & $<0.01$ \\
$T_{\mathrm{s}}$ & 0.578 & 0.182 & 10.2 & 1 & $<0.01$ \\
Log $_{\mathrm{e}}$ YCL & -0.103 & 0.190 & 0.3 & 1 & $\mathrm{~ns}$ \\
DIP & -0.016 & 0.017 & 0.9 & 1 & $\mathrm{~ns}$ \\
Total & & & 69.9 & 34 & \\
Plaice & & & & & \\
$S$ & 0.001 & 0.013 & 0.0 & 1 & $\mathrm{~ns}$ \\
$T_{\mathrm{s}}$ & 0.411 & 0.127 & 4.0 & 1 & $<0.01$ \\
Log $_{\mathrm{e}}$ YCL & -0.418 & 0.146 & 3.1 & 1 & $<0.05$ \\
DIP & 0.024 & 0.010 & 2.2 & 1 & $<0.05$ \\
Total & & & 42.3 & 34 & \\
\hline
\end{tabular}

The annual mean length of sole predicted by Model 2 was affected by both the start of the growing period and temperature during the growing period, whereas year class strength and DIP did not contribute signifi- cantly (Fig. 6, Table 4). Model 4 accounted for almost $70 \%$ of the variation observed, although $50 \%$ of the explained variance could not be ascribed to a single co-variable because of the significant correlation between winter and summer temperature. In contrast to sole, the annual mean length in plaice was not significantly related to the start of the growing period, whereas temperature during the growing period, year class strength and DIP significantly contributed to the variance in length (Fig. 7). Model 4 explained $42 \%$ of the variance in annual mean length in plaice. An increase of $1^{\circ} \mathrm{C}$ in the temperature during the growing period increased autumn length by $0.58 \mathrm{~cm}(\mathrm{SE}=0.18)$ in sole and $0.41 \mathrm{~cm}(\mathrm{SE}=0.13)$ in plaice (Table 4$)$.

\section{BZS data}

Estimates of the daily growth rate were highly variable and increased during spring to reach a peak value at ca. Day 180 (late June to early July) in sole and Day 150 (late May to early June) in plaice (Fig. 8). After Day 200 (mid-July) growth rates were lower in both species. The mean growth rate estimated for the DFS survey period was well within the range of BZS estimates. In sole the growth rates in the period 1975 to 1988 were somewhat lower than in the period 1990 to
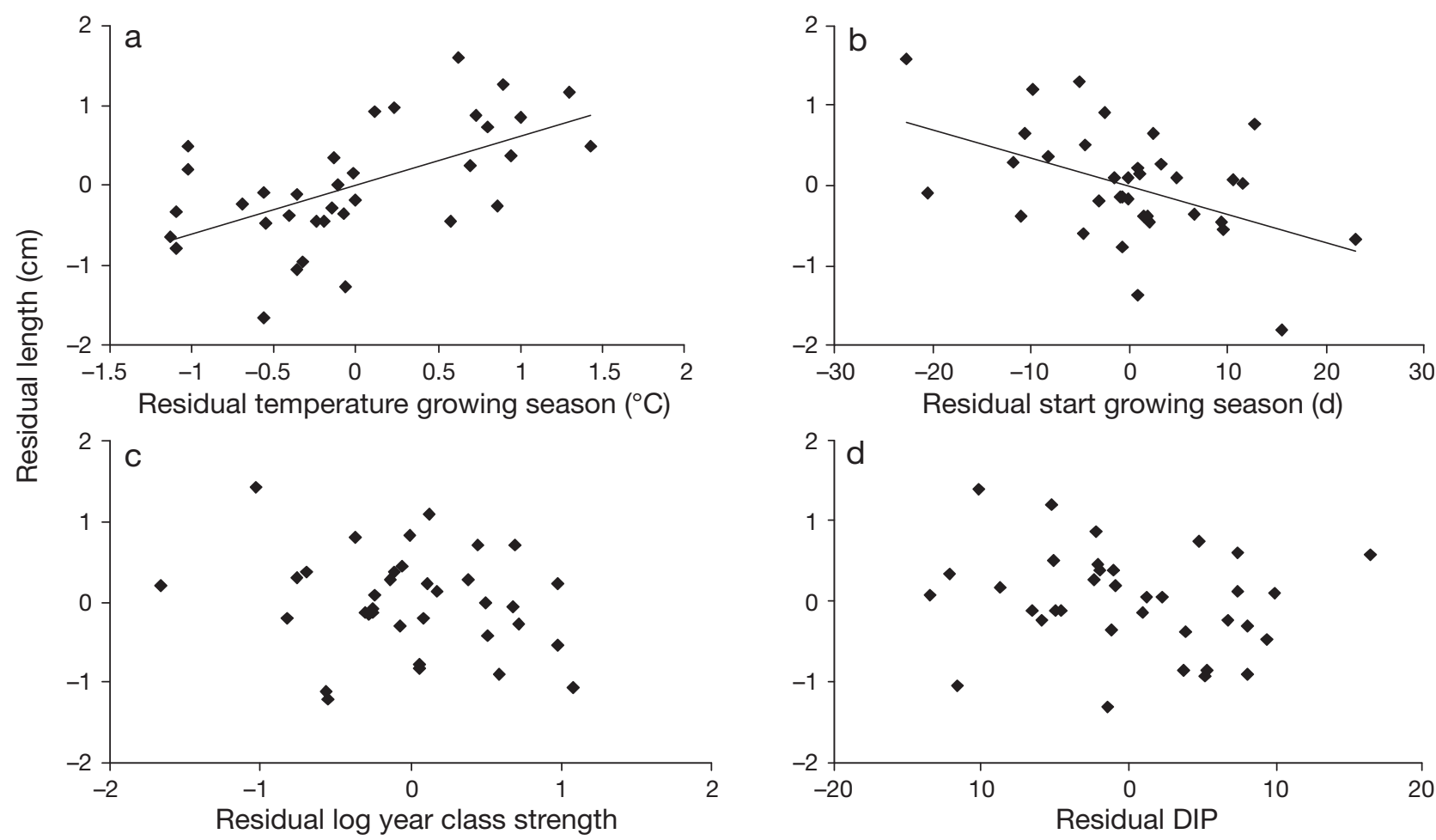

Fig. 6. Solea solea. Model 4 partial regression residual plot of the annual mean 0-group length of sole against (a) the temperature during the growing period, (b) the start of the growing period, (c) log year class strength and (d) eutrophication. Lines show significant linear regression 

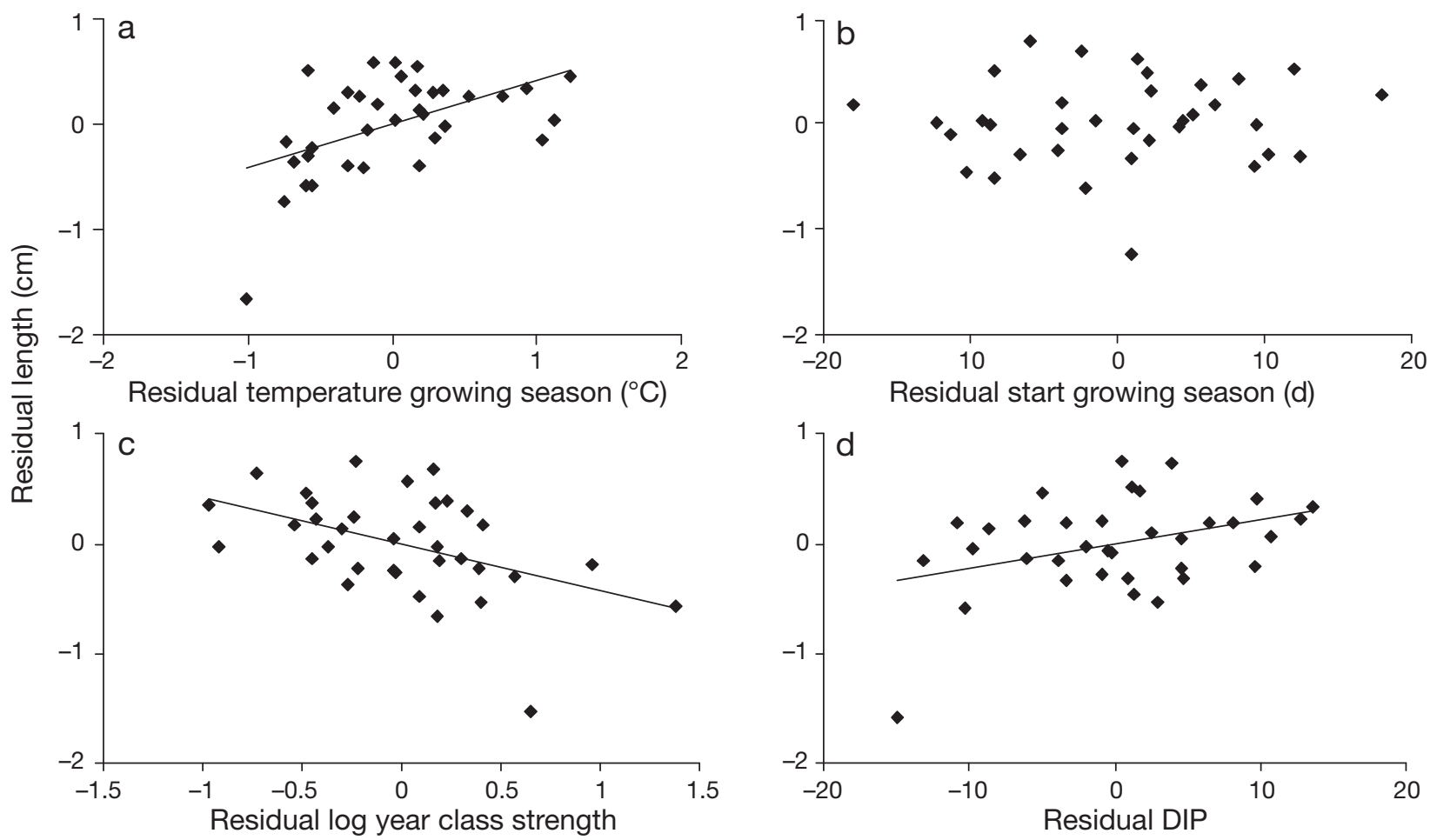

Fig. 7. Pleuronectes platessa. Model 4 partial regression residual plot of the annual mean 0-group length of plaice against (a) the temperature during the growing period, (b) the start of the growing period, (c) log year class strength and (d) eutrophication. Lines show significant linear regression

2002 (linear model with a date < Day 210, p < 0.05). In plaice the growth rates up to Day 150 were higher (linear model with a date < Day 150, p < 0.05), whereas growth rates later than Day 150 tended to be lower in the recent period than in the earlier period $(p<0.01)$.

\section{Comparison of observed growth rates and experi- mental growth rates}

The growth rates estimated from the DFS and BZS were compared to experimental growth rates under ad lib food conditions and at observed temperatures. The comparison was done separately for the relatively cooler period 1970 to 1988 and the warmer period 1989 to 2004. Growth rates estimated from BZS data were below the experimental growth rate in sole, whereas in plaice the observations at Balgzand were around the experimental growth rates in spring but considerably lower in summer (Fig. 8). Also, the mean growth rate in September estimated from DFS data (Model 1) was well below the experimental growth rates and fell within the range of BZS growth rates.

From the parameter estimate of the temperature effect during the growing period of Model 4 and the duration of the growth period, it could be calculated that an increase in temperature of $1^{\circ} \mathrm{C}$ enhanced the growth rate by $0.073 \mathrm{~mm} \mathrm{~d} \mathrm{~d}^{-1}$ per $1^{\circ} \mathrm{C}$ in sole and $0.0243 \mathrm{~mm} \mathrm{~d}^{-1}$ per $1^{\circ} \mathrm{C}$ in plaice. These values are lower than the experimental values $0.113 \mathrm{~mm} \mathrm{~d}^{-1}$ per $1^{\circ} \mathrm{C}$ (sole) and $0.047 \mathrm{~mm} \mathrm{~d}^{-1}$ per $1{ }^{\circ} \mathrm{C}$ (plaice) calculated from the slope of the experimental relationships between growth rate and temperature at the average temperature during the growing period of $17.1^{\circ} \mathrm{C}$ (sole) and $14.2^{\circ} \mathrm{C}$ (plaice).

\section{DISCUSSION}

Our analysis clearly showed that the size of sole and plaice attained at the end of their first year is differentially affected by temperature conditions. In sole, temperature significantly affects both the growth rate and the duration of the growing period, whereas in plaice only growth rate is significantly affected.

\section{Start of growing period and the timing of spawning}

The duration of the growing period is determined by the timing of spawning, which is significantly affected by winter temperature. In plaice the start of the growing season was on average $53 \mathrm{~d}$ later than the end of spawning. In sole this difference was only $19 \mathrm{~d}$. The 


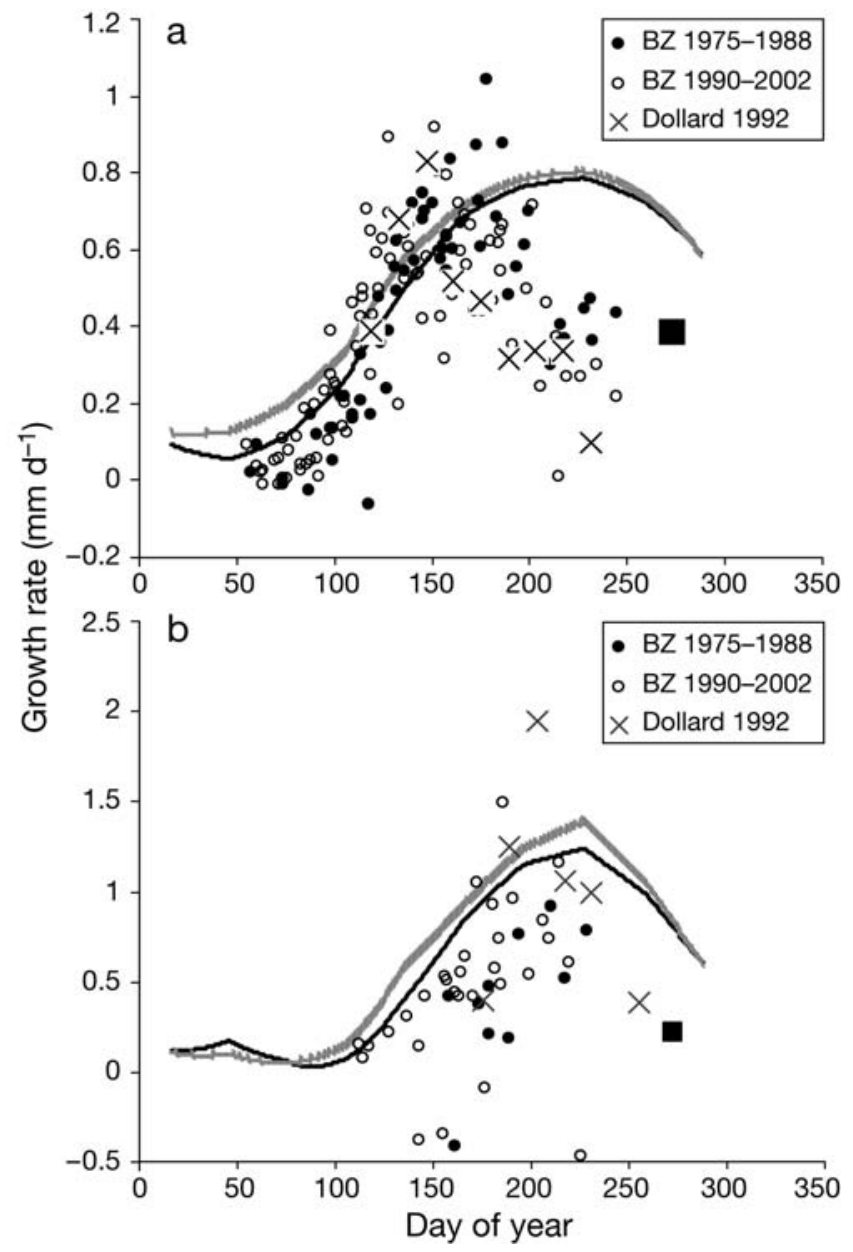

Fig. 8. Solea solea and Pleuronectes platessa. Growth rates $\left(\mathrm{mm} \mathrm{d}^{-1}\right)$ of (a) plaice and (b) sole estimated from the length increment between successive sampling periods on Balgzand (BZ), Dollard (Jager et al. 1995) and the Demersal Fish Survey (DFS) survey $(\mathbf{\square})$. Lines show the expected growth rates according to the experiments of Fonds \& Saksena (1977) and Fonds et al. (1992) for the cooler period 1975 to 1988 and the warmer period 1990 to 2002

difference between the species corresponds to the higher water temperature and smaller egg size in sole, resulting in a shorter development time until metamorphosis (Riley 1973, Fox et al. 2003).

\section{Growth rate}

Seasonal changes in growth estimates from DFS, BZS and the Dollard (estuary of the Ems in the Dutch/German Wadden Sea area) in 1992 (Jager et al. 1995) were similar (Fig. 8), suggesting little local- or habitat-related differences in growth rates. The growth estimates, based on population mean increments in size, showed a sharp drop in growth rates after mid-June. Similar trends in mean length incre- ments during the summer season in the intertidal, subtidal and tidal channels of the western Dutch Wadden Sea (van der Veer \& Witte 1993) suggest the absence of size-selective migration movements of 0-group plaice. This is confirmed by the distribution patterns of 0 group plaice in various depth ranges in the western Wadden Sea that did not change before September (Zijlstra et al. 1982). We therefore assume that the observed population length increments are a good proxy for growth rates.

Plaice growth rates between April and mid-June were close to experimental growth rates at ambient temperatures measured under unrestricted food conditions. The summer growth rates from mid-June onwards, however, were well below the experimental values. The most likely explanations for the strong discrepancy between experimental growth rates and those observed in the field are differences in activity level and food limitation in summer.

Activity levels of wild fish are usually higher than in an experimental setup, potentially influencing growth rates (Rennie et al. 2005). However, we have no information to test for a possible shift from a low activity level in early summer (field and experimental growth rates similar) to a considerable higher activity level after mid-June (lower field growth rates). Alternatively, the occurrence of lower growth rates from mid-June onwards could be explained by food limitation in either the quantity or quality of food. van der Veer \& Witte (1993) hypothesized that the growth of flatfish in their nursery grounds is largely determined by the ambient temperature conditions (the 'maximum growth/optimal food hypothesis'). Our results suggest that this may hold only for the spring and early summer conditions but not later in summer when food requirements of 0-group flatfish populations (van der Veer et al. 2000a) and other epifauna components, such as gobies and crustaceans, reach a peak in biomass (Kuipers 1977). Food-limited growth is also supported by Berghahn et al. (1995), who showed that size of 0-group plaice differed substantially between 2 locations within the nursery area and correlated with both the local abundance and the quality of food resources. Several papers provided strong evidence for the occurrence of densitydependent growth during the juvenile phase in plaice (Modin \& Pihl 1994, Rijnsdorp \& van Leeuwen 1992, 1996), but not in sole (van der Veer et al. 1991, Rogers 1994, Amara 2003, 2004). In recent years the probability of food limitations may have increased due to a decrease in primary and secondary (benthic) productivity of the system following the reduction in nutrient concentrations in the coastal waters since the 1980s (Lenhart, 2001, Philippart et al. 2007), in line with the significant contribution of the eutrophication parameter DIP to the variation in growth of plaice. 


\section{Implications of climate change}

We showed that an increase in temperature affects the size of 0-group sole and plaice at the end of their first year by advancing the start of the growing period and by affecting the growth rate during the growing period. A further increase in temperature as predicted by climate models (Sheppard 2004) will impact sole and plaice differentially. The relationships between the timing of spawning and winter temperatures suggest that a further temperature increase may advance spawning in sole and lead to a further increase in the duration of the growing period, but will not greatly affect the timing of spawning in plaice.

A further increase in summer temperature is expected to lead to a further increase in the growth rate in sole, as the optimum temperature is close to $24^{\circ} \mathrm{C}$ (Fonds \& Saksena 1977). However, for plaice the growth rate is likely to be negatively affected when the temperature increases above $20^{\circ} \mathrm{C}$, beyond which the growth rate will start to decrease (Fonds et al. 1992). This may lead to a movement of young plaice to deeper and cooler waters, as has already occurred in recent years (Van Keeken et al. 2007). Warm temperatures around August may further strengthen the food limitation if secondary production cannot keep up with the increased food requirements of the flatfish population. As the primary production in coastal waters such as the Wadden Sea is mainly determined by light and nutrients (Colijn \& Cadée 2003), an increase in summer temperature due to global warming may raise the food requirements of the secondary and tertiary consumers above primary production and result in a reduction of the quality of the coastal waters as a nursery area for 0-group flatfish. At present some of the food items of juvenile flatfishes such as bivalves already suffer from severe food limitation during the summer period (Cardoso et al. 2006). Furthermore, the observed differences in temperature preference and sensitivity (range, $Q_{10}$ ) between secondary and tertiary consumers in the Wadden Sea will also affect predator-prey interactions and the ultimate food conditions and resulting growth (Freitas et al. 2007).

Acknowledgements. We acknowledge the Royal Netherlands Institute for Sea Research (NIOZ, Texel, Netherlands), Deutsches Ozeanographisches Datenzentrum of the Bundesamt für Seeschifffahrt und Hydrographie (Hamburg, Germany) and Vlaamse Hydrografie, Afdeling Kust (Oostende, Belgium) for providing data on sea surface temperatures. This study is partly funded through Kennisbasis WOT, BSIK Kiss and the FP6 project RECLAIM (Contract no. 044133 - FISH REG/A3(2006)D/14751). The paper has benefited from the comments of 3 anonymous reviewers.

\section{LITERATURE CITED}

Amara R (2003) Seasonal ichthyodiversity and growth patterns of juvenile flatfish on a nursery ground in the Southern Bight of the North Sea (France). Environ Biol Fish 67:191-201

Amara R (2004) 0-group flatfish growth conditions on a nursery ground (Bay of Canche, Eastern English Channel). Hydrobiologia 518:23-32

Beare DJ, Batten S, Edwards M, Reid DG (2002) Prevalence of boreal Atlantic, temperate Atlantic and neritic zooplankton in the North Sea between 1958 and 1998 in relation to temperature, salinity, stratification intensity and Atlantic inflow. J Sea Res 48:29-49

Beaugrand G (2004) The North Sea regime shift: evidence, causes, mechanisms and consequences. Prog Oceanogr 60:245-262

Becker GA, Pauly M (1996) Sea surface temperature changes in the North Sea and their causes. ICES J Mar Sci 53:887-898

Berghahn R, Ludemann K, Ruth M (1995) Differences in individual growth of newly settled 0-group plaice (Pleuronectes platessa L) in the intertidal of neighbouring Wadden Sea areas. Neth J Sea Res 34:131-138

Beukema JJ (1992) Expected changes in the Wadden Sea benthos in a warmer world: lessons from periods with mild winters. Neth J Sea Res 30:73-79

Beukema JJ, Cadée GC (1988) Zoobenthos responses to eutrophication of the Dutch Wadden Sea. Ophelia 26:55-64

Beukema JJ, Cadée GC, Dekker R (2002) Zoobenthic biomass limited by phytoplankton abundance: evidence from parallel changes in two long-term data series in the Wadden Sea. J Sea Res 48:111-125

Boddeke R, Hagel P (1995) Eutrophication, fisheries, and productivity of the North Sea continental zone. In: Armantrout NB, Wolotira RJ (eds) Condition of the world's aquatic habitats. Proc World Fish Cong, Theme I. Oxford \& IBH Publishing, New Delhi, p 290-315

Cadée GC, Hegeman J (2002) Phytoplankton in the Marsdiep at the end of the 20th century; 30 years monitoring biomass, primary production, and Phaeocystis blooms. J Sea Res 48:97-110

Cardoso JFMF, Witte JIJ, van der Veer HW (2006) Intra- and interspecies comparison of energy flow in bivalve species in Dutch coastal waters by means of Dynamic Energy Budgets (DEB theory). J Sea Res 56:182-197

Colijn F, Cadée GC (2003) Is phytoplankton growth in the Wadden Sea light or nitrogen limited? J Sea Res 49:83-93

Colijn F, Hesse KJ, Ladwig N, Tillmann U (2002) Effects of the large-scale uncontrolled fertilisation process along the continental coastal North Sea. Hydrobiologia 484:133-148

de Roos AM, Persson L (2002) Size-dependent life-history traits promote catastrophic collapses of top predators. Proc Natl Acad Sci USA 99:12907-12912

de Veen JF (1970) On some aspects of maturation in the common sole Solea solea (L.). Ber Dtsch Wiss Komm Meeresforsch 21:78-91

Fonds M, Saksena VP (1977) The daily food intake of young soles (Solea solea L.) in relation to their size and water temperature. Actes Colloq Int 4: 51-58

Fonds M, Cronie R, Vethaak AD, van der Puyl P (1992) Metabolism, food consumption and growth of plaice (Pleuronectes platessa) and flounder (Platichthys flesus) in relation to fish size and temperature. Neth J Sea Res 29:127-143

Fox CJ, Geffen AJ, Blyth R, Nash RDM (2003) An evaluation of the temperature dependent development rates of plaice (Pleuronectes platessa L.) eggs from the Irish Sea. J Plankton Res 25:1319-1329 
Freitas V, Campos J, van der Veer HW (2007) Potential impact of temperature change on epibenthic predator-bivalve prey interactions in temperate estuaries. J Therm Biol 32: 328-340

Genner MJ, Sims DW, Wearmouth VJ, Southall EJ, Southward AJ, Henderson PA, Hawkins SJ (2004) Regional climatic warming drives long-term community changes of British marine fish. Proc R Soc Lond B Biol Sci 271: 655-661

Harding D, Nichols JH, Tungate DS (1978) The spawning of the plaice (Pleuronectes platessa L.) in the southern North Sea and English Channel. Rapp P-V Reùn Cons Int Explor Mer 172:102-113

Heessen HJL, Rijnsdorp AD (1989) Investigations on egg production and mortality of cod (Gadus morhua L.) and plaice (Pleuronectes platessa L.) in the southern and eastern North Sea in 1987 and 1988. Rapp P-V Reùn Cons Int Explor Mer 191:14-20

ICES (2005) The Annual ICES Ocean Climate status summary 2004/2005. ICES Coop Res Rep 275

ICES (2006a) Report of the Planning Group on North Sea Cod and Plaice Egg Surveys in the North Sea (PGEGGS). ICES CM 2006/LRC:02

ICES (2006b) Report of the ICES Advisory Committee on Fishery Management, Advisory Committee on the Marine Environment and Advisory Committee on Ecosystems, 2006, Book 6. ICES Advice Series, Books 1-10, ICES, Copenhagen

Jager Z, Keef HL, Tydeman P (1995) Mortality and growth of 0-group flatfish in the brackish Dollard (Ems estuary, Wadden Sea). Neth J Sea Res 34:119-129

Kröncke I, Dippner JW, Heyen H, Zeis B (1998) Long-term changes in macrofaunal communities off Norderney (East Frisia, Germany) in relation to climate variability. Mar Ecol Prog Ser 167:25-36

Kuipers BR (1977) On the ecology of juvenile plaice on a tidal flat in the Wadden Sea. Neth J Sea Res 11:56-91

Lenhart HJ (2001) Effects of river nutrient load reduction on the eutrophication of the North Sea, simulated with the ecosystem model ERSEM. Senckenb Marit 31: 299-311

Millner RS, Whiting CL (1996) Long-term changes in growth and population abundance of sole in the North Sea from 1940 to the present. ICES J Mar Sci 53:1185-1195

Modin J, Pihl L (1994) Differences in growth and mortality of juvenile plaice Pleuronectes platessa L., following normal and extremely high settlement. Neth J Sea Res 32: 331-341

Nash RDM, Geffen AJ, Hughes G (1994) Individual growth of juvenile plaice on an Irish Sea nursery ground (Port Erin Bay, Isle of Man). Neth J Sea Res 32:369-378

Philippart CJM, Van Aken HM, Beukema JJ, Bos OG, Cadée GC, Dekker R (2003) Climate-related changes in recruitment of the bivalve Macoma balthica. Limnol Oceanogr 48:2171-2185

Philippart CJM, Beukema JJ, Cadée GC, Dekker R and others (2007) Impact of nutrient reduction on coastal communities. Ecosystems 10:96-118

Pihl L (1989) Abundance, biomass and production of juvenile flatfish in southeastern Kattegat. Neth J Sea Res 24:69-81

Reid PC, Planque B, Edwards M (1998) Is observed variability in the long-term results of the Continuous Plankton Recorder survey a response to climate change? Fish Oceanogr 7:282-288

Reise K (1982) Long-term changes in the macrobenthic invertebrate fauna of the Wadden Sea: Are polychaetes about to take over? Neth J Sea Res 16:29-36
Rennie MD, Collins NC, Shuter BJ, Rajotte JW, Couture C (2005) A comparison of methods for estimating activity costs of wild fish populations: more active fish observed to grow slower. Can J Fish Aquat Sci 62:767-780

Rijnsdorp AD (1989) Maturation of male and female North Sea plaice (Pleuronectes platessa L.). J Cons Int Explor Mer 46: 35-51

Rijnsdorp AD, van Leeuwen PI (1992) Density-dependent and independent changes in somatic growth of female North Sea plaice Pleuronectes platessa between 1930 and 1985 as revealed by back-calculation of otoliths. Mar Ecol Prog Ser 88:19-32

Rijnsdorp AD, van Leeuwen PI (1996) Changes in growth of North Sea plaice since 1950 in relation to density, eutrophication, beam-trawl effort, and temperature. ICES J Mar Sci 53:1199-1213

Rijnsdorp AD, Grift RE, Kraak SBM (2005) Fisheries-induced adaptive change in reproductive investment in North Sea plaice (Pleuronectes platessa)? Can J Fish Aquat Sci 62: 833-843

Riley JD (1973) The distribution and mortality of sole eggs (Solea solea L.) in inshore areas. In: Blaxter JHS (ed) Early life history of fish. Springer-Verlag, New York, p 39-52

Rogers SI (1994) Population density and growth rate of juvenile sole Solea solea (L.). Neth J Sea Res 32:353-360

Scheffer M, Carpenter SR (2003) Catastrophic regime shifts in ecosystems: linking theory to observation. Trends Ecol Evol 18:648-656

Sheppard C (2004) Sea surface temperature 1871-1999 in 14 cells around the United Kingdom. Mar Pollut Bull 49: 12-16

van Aken HM (2003) 140 years of daily observations in a tidal inlet (Marsdiep). ICES Mar Sci Symp 219:359-361

> van Beek FA, Rijnsdorp AD, De Clerck R (1989) Monitoring juvenile stocks of flatfish in the Wadden Sea and the coastal areas of the southeastern North Sea. Helgol Meersunters 43:461-477

van der Land MA (1991) Distribution of flatfish eggs in the 1989 egg surveys in the southeastern North Sea, and mortality of plaice and sole eggs. Neth J Sea Res 27: $277-286$

van der Land MA, Heessen HJL, Rijnsdorp AD (1990) The results of the 1989 egg surveys for cod and plaice. ICES CM 1990/G:27

van der Veer HW, Witte JIJ (1993) The 'maximum growth/ optimal food condition' hypothesis: a test for 0-group plaice Pleuronectes platessa in the Dutch Wadden Sea. Mar Ecol Prog Ser 101:81-90

van der Veer HW, Bergman MJN, Dapper R, Witte JIJ (1991) Population dynamics of an intertidal 0-group flounder Platichthys fiesus population in the western Dutch Wadden Sea. Mar Ecol Prog Ser 73:141-148

van der Veer HW, Berghahn R, Rijnsdorp AD (1994) Impact of juvenile growth on recruitment in flatfish. Neth J Sea Res 32:153-173

van der Veer HW, Berghahn R, Miller JM, Rijnsdorp AD (2000a) Recruitment in flatfish, with special emphasis on North Atlantic species: progress made by the Flatfish Symposia. ICES J Mar Sci 57:202-215

van der Veer HW, Geffen AJ, Witte JIJ (2000b) Exceptionally strong year classes in plaice Pleuronectes platessa: Are they generated during the pelagic stage only, or also in the juvenile stage? Mar Ecol Prog Ser 199:255-262

van der Veer HW, Dapper R, Witte JIJ (2001) The nursery function of the intertidal area in the western Wadden Sea for 0-group sole Solea solea (L.). Neth J Sea Res 45: $271-279$ 
van Keeken OA, van Hoppe M, Grift RE, Rijnsdorp AD (2007) The implications of changes in the spatial distribution of juveniles for the management of North Sea plaice (Pleuronectes platessa). J Sea Res 57:187-197

van Raaphorst W, de Jonge VN (2004) Reconstruction of the total $\mathrm{N}$ and $\mathrm{P}$ inputs from the IJsselmeer into the western Wadden Sea between 1935-1998. J Sea Res 51:109-131

Weijerman M, Lindeboom H, Zuur AF (2005) Regime shifts in marine ecosystems in the North Sea and Wadden Sea. Mar Ecol Prog Ser 298:21-39

Editorial responsibility: Otto Kinne, Oldendorf/Luhe, Germany
Whitehead PJP, Bauchot ML, Hureau JC, Nielsen J, Tortonese E (1986). Fishes of the north-eastern Atlantic and the Mediterranean, Vol 3. UNESCO, Paris

Zijlstra JJ (1972) On the importance of the Wadden Sea as a nursery area in relation to the conservation of the southern North Sea fishery resources. Symp Zool Soc Lond 29: $233-258$

Zijlstra JJ, Dapper R, Witte JIJ (1982) Settlement, growth and mortality of post-larval plaice (Pleuronectes platessa) in the western Wadden Sea. Neth J Sea Res 15:250-272

Submitted: December 6, 2005; Accepted: December 4, 2007 Proofs received from author(s): March 17, 2008 